\title{
The Determinants of Liquidity of Commercial Banks in Bangladesh: An Exploratory Study
}

\author{
Firoja Akter Khanam \\ Professor, Department of Finance, Chittagong University \\ Kamrul Hasan*
}

Associate Professor, Department of Accounting, American International University-Bangladesh (AIUB)

\begin{abstract}
The main aim of the paper is to investigate the liquidity determinants of commercial banks of Bangladesh. The study has applied Pooled OLS Regression analysis to a panel data of 20 scheduled commercial banks for the period 2008 to 2019. Both asset-based indicator of liquidity (LQ $)$ (Liquid assets to total assets) and liabilitybased indicator of liquidity of banks $\left(\mathrm{LQ}_{2}\right)$ (total loans to total deposit ratio) have been undertaken as dependent variable. The results indicate that among the bank-specific factors, capital adequacy ratio, deposits ratio, and return on assets are found to have positive impact on bath $\mathrm{LQ}_{1}$ and $\mathrm{LQ}_{2}$. While bank size, asset quality and profitability have negative impact on both $\mathrm{LQ}_{1}$ and $\mathrm{LQ}_{2}$. With respect to macro-economic variables, the results indicate that GDP has positive and significant effect on both $\mathrm{LQ}_{1}$ and $\mathrm{LQ}_{2}$ and Inflation has negative and insignificant impact on both $\mathrm{LQ}_{1}$ and $\mathrm{LQ}_{2}$. The commercial banks and Bangladesh bank should give emphasis for the above-mentioned ratios to achieve smooth liquidity management and to reduce liquidity risk. The study recommended that bankers should reduce the nonperforming loans for smooth functioning of operation.
\end{abstract}

Keywords: Bank liquidity, asset quality, capital adequacy ratio, profitability, economic growth, and inflation.

DOI: $10.7176 /$ RJFA/12-19-02

Publication date:October $31^{\text {st }} 2021$

\subsection{Prelude}

In today's developing and competitive world, the banking sector has emerged as a key player that contributes to the growth of economy, development of financial sector and more importantly, creation of employment in the country. The major role of banks is to collect money from the public in the form of deposits and then along with its own funds to serve the demands of the customers quickly, paying interest for the deposits and meet out expenses to carry out its activities. For this purpose, banks maintain adequate liquidity and earn profits from the activities.

The liquidity of a bank is critically important for bank success. It is a "measure of bank's ability to find ready cash, short-term creditworthy securities, government bills, etc., which can be readily converted into cash (Elliot, 2015). Liquidity of banks means the capability of a bank to meet its obligations due at any times specially to repay customer deposits to make a payment on the client's order (Vodova, 2016). Liquidity mismanagement is mainly caused by a mismatch between assets and liabilities of commercial banks (Saunders \& Cornett, 2005). Poor liquidity management may affect earnings and capital. In extreme cases it may lead to insolvency and bank failure. Customer's confidence is mostly depending on how efficiently a bank handles its liquidity. A bank having good asset quality, strong earnings and sufficient capital may fail if it is not maintaining adequate liquidity (Crowe, 2009).

After the global financial crisis, the bank for International Settlements has initiated several regulatory reforms aimed to manage the short-term liquidity of Banks (BIS, 2010). Basel Committee (2010) was thus issued a framework for measuring and managing liquidity which sets out principles for assessment and management of liquidity in Banks. For short-term liquidity management, it proposed to the Liquidity coverage ratio and for longterm liquidity management it proposed Net stable funding Ratio. Apart from internal management strategy and policy on Liquidity management by banks, BIS (2010) emphasized the role of supervisors in monitoring liquidity strategy of individual banks.

In order to manage their liquidity positions, banks can follow one of three strategies, viz, assets liquidity management, liabilities liquidity management or balanced liquidly management. When conducting assets liquidity management, banks hold liquid assets in periods of positive liquidity and sell these liquid assets in periods of negative liquidity), Liabilities liquidity management involves banks borrowing funds to cover liquidity shortfalls. Finally, balanced liquidity management means banks will use a combination of assets and liabilities strategies to manage their liquidity positions. To describe liquidity determinants of banks, there are two most widely used approaches liquidity gap approach (flow approach) and liquidity ratio approach (stock approach). Though both approaches are intuitively applying the liquidity, ratio approaches are more common in practice due to the availability of a more standardized method (Edem, in 2017, Laurine, 2013).

According to Bangladesh bank, all scheduled banks must maintain Cash Reserve Ratio (CRR) averaging 5.5 
percent daily on a biweekly basis against average total demand and time liabilities (ATDTL) of the second preceding month, with an obligation to maintain daily minimum 5.0 percent cash against the same ATDTL held by the bank (Bangladesh bank, Annual Report, 2019). The current rate of SLR (Statutory liquidity reserve) for conventional banks is 13.0 percent of ATDTL. On the other hand, for Islamic Shariah based banks, the rate of SLR is 5.5 percent of their ATDTL. It is reported that two specialized banks and BDBL are exempted from maintenance of SLR, but these banks have to maintain CRR at the same rate as other scheduled banks with Bangladesh Bank in cash. (Bangladesh Bank, Annual Report, 2019.)

\subsection{Literature Review}

A few empirical studies have explored the determinants of bank liquidity where different scholars adopted different explanatory variables in examining the determinants of liquidity of commercial banks across countries.

Singh and Sharma (2016) have analyzed that bank size, profitability, deposits, and capital adequacy are some important bank-specific factors while gross domestic product and inflation are few important macro-economic variables that have significant impact on liquidity. Finally results show that bank ownership also affects the bank liquidity. Omer et al. (2015) observed that financing to government to fill the gap of budget deficit by the central bank is an important determinant of excess liquidity. Furthermore, they found that monetary policy is less effective if banks hold excess liquidity for unexpected needs. Fungacova and Weill, (2012) in their study on Russian banks, observed the low level of financial development in Russia because of low liquidity creation in the economy. Vodova (2012) show that capital ratio, interest rate, nonperforming loans and interbank transactions are positively linked to bank liquidity. The study employed two most convenient liquidity measures, loan to deposit, ratio, and liquid asset to deposit ratios as dependent variable. Alkaeli (2006) found out that bank size, profitability and interest rates are related inversely while capital ratio, interbank transactions and non-performing loans are directly linked to bank liquidity. Al-Homaidi et al. (2019), has undertaken bank liquidity as the dependent variable and considered various bank specific factors as independent variables such as bank size, capital adequacy ratio, deposit ratio, operation efficiency ratio, asset quality ratio, asset management ratio, return on equity ratio, net interest margin, and return on assets. Valla et al. (2006) confirmed that the bank's size has a positive impact on liquidity. The remaining factors are growth of the gross domestic product, short term interest rates and credit growth that have an inverse relationship with the liquidity of commercial banks in France. Calmoiris et al. (2013) proved that it is necessary to hold more cash, which plays a significant role in supporting for the commercial banks remain stable liquid status, because the bank has the capacity to encounter mass withdrawals which causes bank illiquidity. DeYoung et al. (2018) concluded that a minimum capital compulsion significantly mitigates liquidity danger at the banks. Vu (2012) through statistical analysis, disproportionate correlation and regression of data with the fixed effect, the study found the impact of some factors on liquidity. Specifically, the equity ratio, bad debt ratio and profit ratio positively correlated while the ratio of loans on deposits negatively correlated with the liquidity of Vietnamese commercial banks.

\subsection{Objectives of the study}

The main objective of the study is to explore the major determinants of liquidity of commercial banks in Bangladesh. To achieve the main objective the following specific objectives have been covered:

1. To analyze the liquidity trend of banking sector of Bangladesh.

2. To explore the bank specific determinants of liquidity of banks.

3. To examine the macroeconomic determinants of liquidity of banks.

4. To put policy framework for effective liquidity management.

\subsection{Methodology of the Study}

Both primary and secondary data have been used in the study. For primary data collection a semi structured questionnaire has been prepared and opinions of expert bankers have been collected through direct interview. For secondary data collection, Annual report of sample banks, Bangladesh Bank annual report, Economic Review, Economic Trend, Statistical Yearbook, different related books, journal, dissertations have been studied. The bank specific variables such as assets size, capital adequacy, deposits, of asset quality, profitability to operation efficiency and the macroeconomic variables such as GDP and Inflation rate are selected for the present study from extensive literature survey. The sample of this research is based on the panel data that consists of selected public and private Commercial banks for a period of from 2010 to 2018. The criteria for selection of these banks are based on the availability of data for the period covered by this research. The total numbers of Scheduled Banks in Bangladesh in 2019 are 57 which include State-owned commercial banks (SCBs), Stateowned development financial institutions (DFIs), Private commercial banks (PCBs) and Foreign commercial banks (FCBs). Out of 57 banks, the required number of sample (n) has been selected using simple random sampling (SRS). The required number of sample size is 36 banks. Out of 36 banks, by applying convenience sampling technique we will select 20 banks. Out of 20 banks, 2 are public banks, 10 are private sector banks, 5 
are Islamic banks and 3 are foreign banks.

1.5 Theoretical Framework:

\begin{tabular}{|c|c|}
\hline Independent Variable & Dependent Variable \\
\hline $\begin{array}{l}\text { Bank Specific Variable: Profitability, Deposits, Bank Size, Asset Quality, } \\
\text { Capital Adequacy Ratio } \\
\text { Macro-Economic Variable: Economic Growth (GDP), Inflation Rate }\end{array}$ & Liquidity \\
\hline
\end{tabular}

\subsection{Operationalization of variables}

Table-1 presents the operational definitions of variables. Operational definitions of dependent variable (i.e, liquidity) and independent variables, viz. internal variables (i.e, bank size, profitability, deposits, cost of funds \& capital ratio) and external variables (GDP and Inflation rate) are adopted from earlier empirical studies relevant to determinants of bank liquidity.

Table-1 Operationalization of Variables

\begin{tabular}{|c|c|c|}
\hline Variables & Symbol & Definition /Description of Measurement \\
\hline \multicolumn{3}{|l|}{ Dependent variable } \\
\hline Liquidity & $\begin{array}{l}\mathrm{LQ}_{1} \\
\mathrm{LQ}_{2}\end{array}$ & $\begin{array}{l}\text { Liquid assets/Total assets } \\
\text { Total loans/Total Deposits }\end{array}$ \\
\hline \multicolumn{3}{|c|}{ Independent variable } \\
\hline \multicolumn{3}{|c|}{ Bank specific variables } \\
\hline $\begin{array}{l}\text { Profitability } \\
\text { Bank size } \\
\text { Deposits } \\
\text { Capital ratio } \\
\text { Asset quality } \\
\end{array}$ & $\begin{array}{l}\text { ROA }_{\text {it }} \\
\text { Size }_{\text {it }} \\
\text { Depositit }_{\text {it }} \\
\text { CR }_{\text {it }} \\
\text { NPLratio }_{\text {it }}\end{array}$ & $\begin{array}{l}\text { Profit after taxes / Total assets } \\
\text { Natural log of total asset } \\
\text { Deposits/Total assets } \\
\text { Stockholder equity / Total assets } \\
\text { Non-performing Loans/Total Loans. }\end{array}$ \\
\hline \multicolumn{3}{|c|}{ Macro Economic Variables } \\
\hline $\begin{array}{l}\text { Economic Activity } \\
\text { Inflation rate }\end{array}$ & $\begin{array}{l}\text { GDP } \\
\text { IFR }\end{array}$ & $\begin{array}{l}\text { Annual real GDP growth rate } \\
\text { Annual Inflation rate }\end{array}$ \\
\hline
\end{tabular}

\subsection{Model Specification:}

The specification of determinants of liquidity to be estimated has been formulated in the following equation.

Asset based Indicator of Liquidity:

$\mathrm{LQ}_{1}=\alpha i \mathrm{it}+\beta_{1} \mathrm{ROA}_{\text {it }}+\beta_{2}$ Size $_{\text {it }}+\beta_{3} \mathrm{DTA}_{\text {it }}+\beta_{4} \mathrm{CAR}_{\mathrm{it}}+\beta_{5} \mathrm{NPL}_{\mathrm{it}}+\beta_{6} \mathrm{INFLA}+\beta_{7} \mathrm{GDP}+€$

Liability based Indicator of Liquidity.

$\mathrm{LQ}_{2}=\alpha i \mathrm{it}+\beta_{1} \mathrm{ROA}_{\mathrm{it}}+\beta_{2} \mathrm{Size}_{\mathrm{it}}+\beta_{3} \mathrm{DTA}_{\mathrm{it}}+\beta_{4} \mathrm{CAR}_{\mathrm{it}}+\beta_{5} \mathrm{NPL}_{\mathrm{it}}++\beta_{6} \mathrm{INFLA}+\beta_{7} \mathrm{GDP}+€$

$\mathrm{LQ}_{1}=$ Bank Liquidity (Liquid assets to total assets) Asset-based indicator, $\mathrm{LQ}_{2}=$ Bank Liquidity (Total loans to total deposits) Liability-based indicator. $\beta_{1}, \beta_{2}, \beta_{3}, \beta_{4}, \beta_{5}, \beta_{6}$ and $\beta_{7}$ are the co-efficient of determinant variables and $€$ is the error term. ROA $=$ Profitability (Return on Assets). Size $=$ Bank size (natural $\log$ of total assets), $\mathrm{DEP}=$ Deposits over total assets, CAR $=$ Capital Adequacy Ratio, NPL = Asset Quality (Nonperforming Loan ratio), $\mathrm{OE}=$ Operating Expenses, INFLA = Inflation Rate, GDP = Gross Domestic Product, $€=$ Error term.

\subsection{Variables Explained:}

The following variables are extracted from past literature on bank liquidity.

\section{Dependent variable:}

According to Delechat et al. (2012), bank liquidity (LQ ${ }_{1}$ ) has been calculated as the ratio of liquid assets over total assets and $\mathrm{LO}_{2}$ as total loans to total deposits. Liquidity is required by banks for carrying out daily operations. It facilitates availability of funds in the event of expected and an unexpected cash demands by customers.

Independent variables:

\section{Bank-specific Determinants of bank liquidity}

Capital ratio (CAR)

Capital ratio is an indicator of the equity level in the banking sector. Capital adequacy ratio (CAR) is the ratio of capital that a bank must maintain for absorbing the loss that arises from statutory capital requirements. The relationship of CAR with banks is significant because CAR is larger for banks that are required to maintain less liquidity. It helps banks to stabilizer and recovers for uncertain shocks.

Menicucci and Paolucce (2016) opined that a high capital ratio is good indicator of a bank's stability and liquidity. Repullo (2004) has confirmed this principle by indicating that increasing level of capital will lead to increase the liquidity level and absorb liquidity risk. E I Khoury (2015) in his article on determinants of liquidity 
in the Lebanese banking sector has confirmed that capital level has positive and statistically significant impact on both liquid assets to total assets ratio and liquid assets to deposits ratio. In the case of 36 emerging economics, Bunda and Desquilbet (2008) have found that a high capital level has positive influence over the liquidity of 107 banks. The study of Bonfirm and Kim (2011) also support the idea that banks with a better capital adequacy present a lower liquidity risk exposure. Many other of scholars have found the same positive association between liquid assets to total assets ratio and a bank's capital level (Monteanu, 2012 and Vodova, 2013)

$H_{1:}$ Capital adequacy has positive and significant impact on the liquidity.

\section{Asset Quality (NPL)}

Bloem and Gorter (2001) opined that increasing level of non-performing loans to total loans (Asset Quality Ratio) will decrease depositor's confidence lead to large level of withdrawals and increase the liquidity problem. Another researcher Grzowe et al. (2014) have confirmed this association between liquidity and asset quality by indicating that poor loans quality leads to poor assets quality and poor assets quality leads to a low level of liquidity. According to Melese and Laximkentham (2015) poor loan quality would lead to an efficiency problem. Consequently, banks would diminish their liquidity holdings thus causing the banking system to fail.

$\mathrm{H}_{2}$ : Asset Quality ratio has a negative impact on bank's liquidity.

\section{Profitability of the bank}

Profitability is considered by the different researchers as one of the determinants of banks liquidity. Profitability measured by return on asset (ROA) has a positive impact on liquidity of banks (Singh and Sharma, 2016, Roman \& Sargu 2015). However, Moussa, (2015) found out that the return on asset has as negative impact on the liquidity position of banks.

\section{H3: Profitability has positive and statistically significant impact on the liquidity of banks. Deposit:}

The study of Shah, et.al. (2018) indicated that deposit, measured by share of deposit to total asset has no effect on the level of liquidity. But other studies revealed that deposits had a negative and statistically significant effect on bank liquidity (Singh and Sharma, 2016)

\section{$H_{4}:$ Deposit has a significant negative effect on the liquidity of banks.}

\section{Bank size and liquidity of Bank}

Bank size is defined broadly as the bank's net total asset that is included to capture the economies or diseconomies of scale. Many scholars used natural logarithm of the total assets as the proxy to measure the size of banks (Singh, \& Sharma, 2016, Melese, 2015). The study of Vodova (2011) and Singh and Sharma (2016) indicated that the bank's liquidity is decreasing with the increment of the size of the banks. However other studies of Melese (2015) Mehdi ånd Abderrassol (2014), Malik (2013) and Shaher, et al. (2018) found out that size of bank has a positive effect on the book's liquidity i.e, larger banks are more liquid than smaller banks.

\section{$H_{5:}$ There is a positive and significant impact of size of banks on liquidity.}

Macro-Economic Determinants of Bank liquidity:

\section{Economic Growth}

Economic growth measures the capacity of an economy to produce goods and services in the country and is considered as one of the most important factors that can influence the liquidity of banks (Chaarani, 2018). During economic growth, business activities develop and thus the demands for loans increase. As a result, banks will have more opportunities to give loans when they decrease their liquid assets. This can lead to a negative association between economic growth and liquidity. On the other hand, Treenca et al. (2015), in their article found that economic growth as measured by GDP has a negative and statistically significant impact on bank's liquidity. Similar studies of Vodava (2011) confirmed the negative impact of economic growth on bank liquidity in Czech commercial banks from 2001 to 2009. Other researchers opine that banks prefer to preserve a high level of liquidity during an economic upturn, since they have low confidence in the ability of their customers to repay installments during on economic downturn (Alper, et al. 2012; Chagwiza, 2014; Moussa, 2015). Thus, a positive association exists between bank liquidity and economic growth.

\section{$H_{6:}$ Economic growth has a positive impact on bank's liquidity.}

Inflation:

The impact of inflation rate on bank liquidity has been as a subject of debate in previous studies. Moussa (2015) studied the determinants of liquidity in the Tunisian banking sector from 2000 to 2010. He found a negative association between inflation and banking liquidity. Bunda and Desqulbet (2008) confirmed the negative impact of high inflation rate on the liquidity of banks in emerging economies. A similar result was also found by Vodova (2011) in Crech Banks, Malik and Rafique (2013) in Pakistani banks and EI Khoury (2015) in Lebanese banks.

Other researchers stated that higher inflation would decrease the real rate of return which will discourage banks from giving more loans and encourage them to hold more liquid assets. As a result, a positive association exists between inflation rate, and liquidity level (Treenca et al., 2015)

$H_{7}$ : Inflation has a negative o impact on bank's liquidity. 


\subsection{Liquidity Trend in the Banking Sector}

Effective liquidity management helps to ensure bank's ability to meet cash flow obligations, which are uncertain as they are affected by external events and other agents' behavior. Indicators like advance-deposit ratio (ADR), statutory liquidity ratio (SLR), interbank call money rate, and repo rate show the real picture of liquidity of the banking sector. The following table- 2 and table- 3 show the 5 years data of Advance Deposit ratio and Month wise data of Advance-Deposit ratio in 2019, respectively.

\section{Table-2Banking Sector Year-wise Advance-Deposit Ratio} (In percentage)

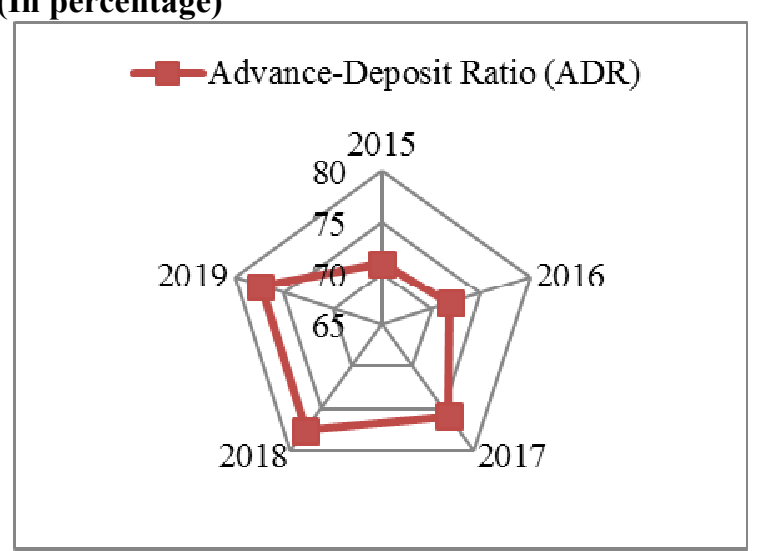

\begin{tabular}{|c|c|}
\hline Year & $\begin{array}{c}\text { Advance-Deposit } \\
\text { Ratio (ADR) }\end{array}$ \\
\hline 2015 & 71.0 \\
\hline 2016 & 71.9 \\
\hline 2017 & 75.9 \\
\hline 2018 & 77.6 \\
\hline 2019 & 77.3 \\
\hline
\end{tabular}

Source: Department of Off-site Supervision, Bangladesh Bank

The banking sector liquidity demonstrated a mixed trend in 2019 as compared to the preceding year as evident from the movement in the advance-to-deposit ratio (ADR). The aggregate ADR of the banking industry slightly decreased to 77.3 percent at end-December 2019 from 77.6 percent at end-December 2018 as the growth of deposits (excluding interbank deposits) outpaced the growth of loans and advances during the review year. Accordingly, the ADR of the banking industry remained below the allowable limit set by Bangladesh Bank (BB).

Table-3 Banking Sector Month-wise Advance-Deposit Ratio in 2019 (In percentage)

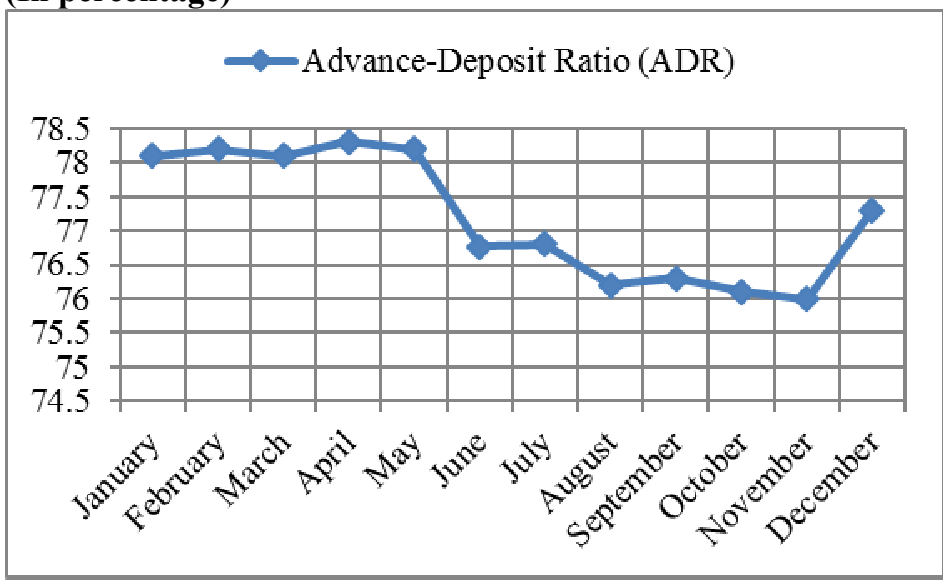

Source: Department of Off-site Supervision, Bangladesh Bank

\begin{tabular}{|l|c|}
\hline \multicolumn{1}{|c|}{ Month } & $\begin{array}{c}\text { Advance-Deposit } \\
\text { Ratio (ADR) }\end{array}$ \\
\hline January & 78.1 \\
\hline February & 78.2 \\
\hline March & 78.1 \\
\hline April & 78.3 \\
\hline May & 78.2 \\
\hline June & 76.77 \\
\hline July & 76.8 \\
\hline August & 76.2 \\
\hline September & 76.3 \\
\hline October & 76.1 \\
\hline November & 76 \\
\hline December & 77.3 \\
\hline
\end{tabular}

From the above Table-3, it is observed that the advanced-deposit ratio increased gradually until April and thereafter showed a declining trend up to August, during September-October the ratio slightly elevated, in November it fell and upturned again at the end of the year. The temporary rising trend in ADR was largely due to additional demand for loan to meet up various business obligation and payment of salaries and allowances of the employees by different organizations during Eid festival. The slight increase at end-December was not prominent due to year-end closing. In a nutshell, overall monthly ADR was less volatile during 2019 and never crossed the regulatory limit during the year. 
1.8 Regression Results of Determinants of liquidity of Bank:

1.8.1 Determinants of Liquidity (LQ $)_{1}$

Table-4 Regression Results of determinants of liquidity (LQ1) of bank

\begin{tabular}{|c|c|c|c|c|c|c|}
\hline \multicolumn{7}{|c|}{ Coefficients } \\
\hline \multirow[t]{2}{*}{ Model } & \multicolumn{2}{|c|}{ Unstandardized Coefficients } & \multicolumn{4}{|c|}{ Standardized Coefficients } \\
\hline & Beta & Std Error & Beta & $\mathbf{t}$ & Sig & VIF \\
\hline (constant) & .072 & .088 & & .814 & .014 & \\
\hline ROA & -.697 & 1.070 & -.394 & --2.652 & $.023 * *$ & 1.421 \\
\hline Deposit & $\mathbf{0 . 1 3 8 9}$ & 0.0322 & .023 & .485 & .534 & 1.321 \\
\hline CAR & .533 & .583 & .585 & 2.949 & $.000 *$ & 1.474 \\
\hline Bank Size & -.026 & .512 & -.027 & -.050 & .654 & 1.98 \\
\hline NPL & -.211 & .521 & -.212 & -2.404 & $.0012 *$ & 1.053 \\
\hline GDP & 1.723 & .968 & 1.71 & 3.78 & $.023 * *$ & 1.21 \\
\hline IFL & .282 & .563 & .271 & .847 & .532 & 1.311 \\
\hline
\end{tabular}

R-Squared-0.861, Adjusted R-Squared 0.742. F-Statistics .959, Prob (F-Stat) .000

Note: *Significance at 1\% level, and **5\% level, Source: Data have been compiled by the Researcher

Table-4 depicted the regression result of liquidity as the dependent variable and five bank- specific and two macro-economic variables as explanatory variables of sample commercial banks for the period $2010-2019$. The overall goodness of the model was measured using the adjusted R-square whose value was $72.4 \%$ for model LQ1.This means that the model employed in the study has good predicting power. F-Statistics for the model is significant at $1 \%$ percent level. It is also revealed from co-efficient that capital adequacy has positive and significant impact on liquidity which corroborates the research (Monteanu, 2012 and Vodova, 2013). The positive influence of share of capital on liquidity is consistent with the assumption that a bank with sufficient capital adequacy should be liquid as well.

Asset Quality as measured by non-performing loan ratio has negative and significant impact on liquidity and this research is similar with Bloem and Gorter (2001). Further the findings shows that profitability has negative relationship with liquidity and significant impact on liquidity which is consistent with economic theory. The result is tandem with the result of Moussa (2015), but contrary to the findings of (Singh and Sharma, 2016, Roman \& Sargu 2015).

It is observed that bank size is negative and insignificant effect on liquidity. The result of the findings is consistent with the research of Vodova (2011) and Singh and Sharma (2016). The research also reveals that there is no significant impact of deposit on liquidity of bank which is consistent with the research of Shah, et al. (2018).

In line with the hypothesis, the result of the study indicates that GDP has positive and significant impact on Liquidity at 5\%significance level and this research is consistent with the research of (Alper, et al., 2012; Chagwiza, 2014; Moussa, 2011). Finally, consistent with expectations, the result of the current study indicates that annual inflation positively but insignificantly affects the liquidity of banks. The regression result indicates that when inflation of the country increases by $1 \%$ being other factors held constant, there will be 27 percent increase of bank liquidity measured by $\mathrm{LQ}_{1}$.

1.8.2 Determinants of Liquidity $\left(\mathrm{LQ}_{2}\right)$

Table:5 Regression Results of determinants liquidity $\left(\mathrm{LQ}_{2}\right)$ of bank Coefficients

\begin{tabular}{|c|c|c|c|c|c|c|}
\hline Model & \multicolumn{2}{|c|}{ Unstandardized Coefficients } & \multicolumn{4}{|c|}{ Standardized Coefficients } \\
\hline & Beta & Std Error & Beta & t & Sig & VIF \\
\hline constant) & $\mathbf{6 6 . 6 0 7}$ & $\mathbf{1 . 5 5 8}$ & & $\mathbf{4 4 . 6 9 0}$ & .014 & \\
\hline ROA & $\mathbf{- 2 . 7 0 5}$ & .143 & -.449 & -18.975 & $.000^{*}$ & 1.061 \\
\hline Deposit & $\mathbf{0 . 1 4 8 9}$ & $\mathbf{0 . 0 3 3 2}$ & .502 & 4.48 & .518 & 1.032 \\
\hline CAR & $\mathbf{2 . 9 2 9}$ & .113 & .620 & 2.931 & $.000^{*}$ & 1.041 \\
\hline Bank Size & $\mathbf{- . 0 2 3}$ & .511 & -.0350 & -.0450 & .556 & 1.98 \\
\hline NPL & $\mathbf{- 1 . 6 0 7}$ & .080 & -.472 & -2.125 & $.057^{* *}$ & 1.020 \\
\hline GDP & .121 & .023 & .344 & 5.26 & $.000 *$ & 1.324 \\
\hline IFL & -.191 & .088 & .324 & -1.17 & .532 & 1.435 \\
\hline
\end{tabular}

R-Squared-0.76, Adjusted R-Squared 0.58, F-Statistics 6.813, Prob (F-Stat) .000

Note: *Significance at $1 \%$ level, and $* * 5 \%$ level, Source: Data have been compiled by the Researcher

Table -5 reveals that the regression model illustrates that the value of Adjusted R-Square is 0.58 which reveals that both internal determinants and external variables contribute about $57 \%$ to the Liquidity (LQ2). It is also observed that F-Statistics is significant at $1 \%$ level. Regression results indicate that capital adequacy is positively related to liquidity and the relationship is significant. The results supported the findings of Spiteri and 
Grima, (2019). Further it is observed that asset quality is negatively and significantly related with liquidity. The results consistent with Bloem and Gorter (2001); Melese and Laximkentham (2015) and Grzowe et.al. (2014). It is found that bank size is negative and insignificant effect on liquidity. The result of the findings is consistent with the research of Vodova (2011) and Singh and Sharma (2016).

The results also show that deposit is negatively but insignificantly related with liquidity. Since deposits are life blood of any bank, inflow of cash through deposits diminishes the need to hold more liquid assets. These findings corroborate with the research of Singh and Sharma, (2016). Further the findings show that profitability has negative and significant impact on liquidity which is consistent with the result of Moussa (2015), but contrary to the findings of (Singh and Sharma, 2016, Roman \& Sargu 2015).

In terms of macroeconomic determinants, the findings reveal that GDP has a positive effect on liquidity while Inflation has negative impact of liquidity. The findings supported by Sing and Sharma (2016 who showed that GDP has a significant effect on Liquidity. It also supported by Choon et.al. (2013), Moussa (2015), and Bunda and Desquilbet (2008) who have indicated that GDP has a positive impact on bank's liquidity. It is inconsistent with Valla, Saes-Escorbiac and Tiesset (2016) Aspachs (2005) and Vodova (2011) who found that GDP has a negative impact on bank liquidity. Further the result is consistent with the findings of Moussa (2015) and Bunda and Desqulbet (2008), that inflation rate has negative and insignificant effect on Liquidity $\left(\mathrm{LQ}_{2}\right)$.

\subsection{Conclusion}

The objective of the paper is to explore the effects of bank - specific variables and macroeconomic variable son liquidity of commercial banks of Bangladesh for the period 2008 to 2019. The research study has used Pooled OLS regression analysis. The sample size of the study consists of 20 commercial banks which were selected among 57 scheduled banks. Both asset-based liquidity indicator Liquid assets to total asset (LQ $\left.\mathrm{L}_{1}\right)$ and liabilitybased indicator of liquidity loans to deposit ratio $\left(\mathrm{LQ}_{2}\right)$ have been taken as dependent variable. Five bank specific variables and two macroeconomic variables shave been undertaken as independent variable. The bank specific variables included capital adequacy ratio, bank size, deposit ratio, assets quality ratio, profitability ratio, while macroeconomic determinants are Economic Growth (GDP) and inflation rate. The answer to the second objective is that bank-specific variables have substantial effects on liquidity of commercial banks in Bangladesh. For instance, in overall sample of banks, profitability and asset quality is negatively while bank size, deposits, and capital ratio is positively related to liquidity. The answer to the third objective is that bank manager also gives more emphasis on macro factors like GDP when they manage their liquidity.

The study suggests that the commercial banks in Bangladesh should be more concerned with the bank specific variables as a cornerstone of their policy and in formulating strategies to enhance their liquidity position. Resultantly the bank manager may manage the liquid assets in a better way by keeping in mind the statutory requirements set by the Central Bank. The bank manager also gives importance on managing asset quality to reduce the non-performing loans which will increase the profitability of banks. The management should increase its profitability to increase the company's interest income, thus reducing the crisis of liquidity.

\section{Reference}

Arif, A and Nauman, A. (2012) "Liquidity risk and performance of banking system." Journal of financial Regulation and compliance vol. 20, No. (2), pp 182-195.

Aikaeli, J, "Determinants of excess liquidity inn Tanzanian Commercial Bank's (2006), SSRN: https://ssrn.com/abstract $=971750$ or http// dx: doi.org/10.2139/ssrn.971750.

Bunda, I.U., Desquilber, J.B (20080, “The bank liquidity smile across exchange rate regime,", International Economic Journal, Vo.22. No.3 pp.361-386.

Chagwiza, W. (2014), “Zimbabweaun Commercial banks Liquidity and Its Determinants, International Journal of Empirical Finance, Vol.2, No.2, pp.52-64.

Crowe, K. (2009), "Liquidity risk management - more important than ever", Harland Financial Solutions, p. 3.

Calomiris, C. W., Heider, F., \& Hoerova. M. (2013). "A Theory of bank Liquidity requirements" (Columbia Business School Research Paper) No.pp.14-39.

Vu. T.H., (2015), "Factors affecting the liquidity of the commercial banks in Vietnam", Development and Integration, Vol. 23 No. 1 pp.39-49.

DeYong, R. Distinguin, I., \& Tarazi, A., (2018), "The Joint regulation of bank liquidity and bank capital", Journal of Financial Intermediation, Vo. 34, pp.32-46.

Edem, D.B. (2017), "Liquidity Management and Performance of Deposit Money Banks in Nigeria (1988-2011): An Investigation, International Journal of Economics, Finance and Management Science, Vol.5 No.3 pp.146-161.

Fola, B. (2015), factors affecting liquidity of selected commercial bank in Ethiopia (Ph.D Thesis). Addis Ababa University of Retrieved from http://ed.aau.edu.et/bit- stream/handle/123456789/2834/selete\%20Fola.

Funga Cova, z and Weill, L, "Bank Liquidity creation in Russia," Eurasian Geography and Economics Vol. 53, 
No. 2, (2012) pp 285-299.

Laurine, C. (2013), “Zimababwean Commercial banks Liquidity Risk Determinants after Dollarization”, Journal of Appplied Finance \& Bnaking, Vol.3, No.6. pp.97-114.

Matz, L. \& Neu, P. (2007) Liquidity Risk Measurement and Management- A practitioner's Guide to Global Best Practices, Singapore City, J. Wiley.

Muntaeanu, I. (2012), "bank Liquidity and its determinants in Romania, Procedia-Social and Behaviral Sciences, Vo.3 (12), pp.993-998.

Melese, N. (2015), Determinants of Bnaks Liquidity: Empirical Evidence on Ethiopian Commercial banks, Journal of Economics and Sustainable Development, Vol.6, No.15, pp.34-47.

Omer, M, De Haan, J. and scheltens B. (2015). "An empirical analysis of excess interbank liquidity. A case study. Pakistan \& Applied Economis, vol. 47, No. 44, pp 4754-4776.

Ratnovski, L. (2003) "Liquidity and transparency in bank risk management" Journal of financial Intermediation, vol. 22, (3), pp 425439.

Roman, A. \& camelia, A (2015), "The impact of bank-specific factors on the Commercial banks liquidity: Empirical Evidence from CEE countries, Procedia. Economicx and Finance, Vol20. No.15 pp.571-579.

Singh, A. and Sharma, A. K (2010) "An empirical analysis of macroeconomics and bank specific factors affecting liquidity of Indian banks," Future Business Journal vol. 2, PP. 40-53

Syed, Q.A.S., Imran, K, Shaha, M.t., (2018)," Factors Affecting Liquidity of Bnaks: Empirical Evidence from the Banking SEctor of pakistan, Colombo Business Journal, Vol.9, No.1 pp.1-18.

Trenca, I., Petrio, N and Corvai, E.A. (2015), "Impact of macroeconomic variables upon the banking system liquidity. Procedia. Economics and Finance, Vol.32 No.5. pp.1170-1177.

Valla, N, Saes-E-Scerebiae B, and Tiesset, M. (2006), "Bank liquidity and financial stability: financial stability review, 9, 89-104.

Vodova, P, (2011) "Liquidity of Creech commercial Banks and its determinant" International Journal of Mathematical bon models in Applied Sciences, vol.5, No. 6, PP. 962-967. 